\title{
Fission-track evidence of tectonic evolution in the northwestern Qaidam Basin, China
}

\author{
GuO-Qiang Sun ${ }^{1, *}$, Wei-Ming Liu ${ }^{1,2}$, Jia-Jia GuO ${ }^{1,2}$ and Ye-Tong WAng $^{1,2}$ \\ ${ }^{1}$ Key Laboratory of Petroleum Resources, Gansu Province/Key Laboratory of Petroleum Resources Research, \\ Institute of Geology and Geophysics, Chinese Academy of Sciences, Lanzhou 730 000, People's Republic of China. \\ ${ }^{2}$ University of Chinese Academy of Sciences, Beijing 100 049, People's Republic of China. \\ *Corresponding author. e-mail: sguoqiang@lzb.ac.cn
}

MS received 21 February 2017; revised 26 June 2017; accepted 28 June 2017; published online 14 February 2018

Fission-track dating was conducted on zircons and apatites from 11 cores of the upper Xiaganchaigou Formation and lower Shangganchaigou Formation (northwestern Qaidam Basin). The obtained apatite fission-track age is 3.1-61.9 Ma, and the zircon fission-track age is 49.2-123.5 Ma. Although the average apatite age is consistent with ages predicted from the stratigraphy, nine of the 11 apatite fission-track ages have $\mathrm{P}\left(\mathrm{X}^{2}\right)<5 \%$, indicating that the grains experienced heterogeneous annealing after sedimentation. The average zircon age is greater than that indicated by stratigraphy, and all eight zircon fission ages have $\mathrm{P}\left(\mathrm{X}^{2}\right)>5 \%$, exhibiting consistent characteristics and indicating that zircons retain provenance age information after burial. From the zircon and apatite ages, the fission-track length distribution, and the geological setting, the northwestern Qaidam Basin has experienced two tectonothermal events since the Late Mesozoic, at $39.1 \pm 9.3$ to $133.7 \pm 6.6 \mathrm{Ma}$ and $1.2 \pm 0.6$ to $32.0 \pm 3.0 \mathrm{Ma}$. The earlier (39.1$133.7 \mathrm{Ma}$ ) tectonothermal event resulted from the initial collision of the Indian and Eurasian plates. As a consequence of the collision, the Altyn Tagh fault, which forms the northwestern boundary of the Qaidam Basin, began to develop. Subsequently, uplift of the Altyn Tagh mountains began and the northwestern depression of the Qaidam Basin started to form. The later (1.2-32.0 Ma) tectonothermal event resulted from further collision of the Indian and Eurasian plates along the Yarlung Tsangpo suture zone. Strata in the Qaidam Basin were further deformed by transpression in this period and this period played a crucial role in petroleum accumulation.

Keywords. Apatite fission-track; zircon fission-track; tectonic evolution; Qaidam Basin.

\section{Introduction}

Recently, a more advanced fission-track thermochronological method has been used in many types of studies, including the thermal history of sedimentary basins (Kang and Wang 1991; Shi et al. 1998; Wang 1998; Zhu et al. 2004; Bao et al. 2005; Li et al. 2005a; Zheng et al. 2005), rock uplift rates (Wang 1997; Jiang et al. 1998; Wang and Yang 1998; Wu 1999; Wan et al. 2001; Zhao et al. 2003; Yuan et al. 2004), thrusting systems and exhumation history of Himalayan mountain belts (Burbank and Beck 1989; Patel et al. 2007, 2011a,b, 2015; Patel and Carter 2009; Singh et al. 2012; Patel and Singh 2016), thermal history and provenance of sedimentary basins (Patel et al. 2014), age of formation and amount of denudation of sedimentary strata (Wang and Ji 1999; 
Wang 2002; Li et al. 2005b), structural uplift and thermal evolution (Qiu et al. 2000; Chen et al. 2004a), and timing of reactivation of faults/thrusts (Singh et al. 2012).

Previous studies in the Qaidam Basin used outcrop and well-drilling samples for fission-track dating. Wang et al. (2010), who studied the East Kunlun orogenic belt system using fission-track analysis of clastic zircons, thought that the East Kunlun orogenic belt experienced regional tectonic uplift during the Palaeocene and Eocene. Since the Oligocene, the western Qaidam Basin has experienced several episodes of rapid uplift (strong compression) and deposition (Sun et al. 2010; Gao et al. 2011) concurrently with Altyn Tagh fault zone activity (Jolivet et al. 2001; Yin et al. 2002; Liu et al. 2003; Zhang et al. 2012). In the northern basin, the Saishiteng Mountains have undergone at least two large-scale episodes of tectonic activity since the Oligocene (Wan et al. 2011). These tectonic events on the periphery of the Qaidam Basin may have been related to distant effects from the collision of the Indian and Eurasian plates (Mock et al. 1999): this may indicate that distant effects influenced the northern margin of the Tibetan Plateau in the early Cenozoic (Dupont-Nivet et al. 2004; Yin et al. 2008). However, there has been a relative lack of research on the northwestern part of the basin. From fission-track dating analysis of drill-core samples combined with geological data, we demonstrated a coupled relationship between the northwestern Qaidam Basin and the peripheral fault zone.

\section{Geological setting}

The Qaidam Basin, which is located in the northern Tibetan Plateau along the southern margin of the palaeo-Asian tectonic domain, is a large-scale Mesozoic-Cenozoic continental petroliferous basin. The basin has a total area of $120,000 \mathrm{~km}^{2}$ and is bounded by the Qilian range to the northeast, the Kunlun range to the southwest, and the Altyn Tagh range to the northwest (figure 1). These peripheral mountain ranges encompass complicated tectonic dynamic processes (Huang and Chen 1987). The Tethys tectonic domain has opened and closed several times since the Mesozoic, as it gradually subducted and compressed into the palaeo-Asian continent and induced several microblock collisions to the south of the Qaidam Basin (Zhou and Lin
1995). The collision of the Indian and Eurasian plates formed a series of fold mountains, including the Kunlun and Himalaya mountains, and strongly uplifted the Tibetan Plateau (Singer 1992; Dayem et al. 2009). Between the fold mountains, a series of intermountain basins formed and the Qaidam Basin is one of the largest of these. As a result of the unique geographical location and regional structure of this basin, from the early stages of its formation it was affected by many tectonic-dynamic factors. These factors included distant effects stemming from the Indian and Eurasian plates' collision, which had a decisive role in the development and evolution of the basin (Zheng and Peng 1995). The East Kunlun orogenic belt marks a geomorphologic boundary of the Tibetan Plateau, and its structural development in the Cenozoic is thought to be a distant effect of collision and compression between the Indian and Eurasian plates (Dai et al. 2005; Yang et al. 2009). These distant effects also intensified Altyn Tagh fault zone activity at the northwestern boundary of the basin (Yue et al. 2001). Within a very short time after the collision, the Altyn Tagh fault commenced strike-slip movement (Yue et al. 2001, 2003; Zhang et al. 2012). Meanwhile, mountains surrounding the basin and the southern part of the Altyn Tagh fault began to uplift and denude, causing considerable and rapid sedimentation in the fault zone and many basins (Chen et al. 2001, 2004b; Bovet et al. 2009; Pei et al. 2009). The northwestern depression of the Qaidam Basin is located between the East Kunlun and Altyn Tagh mountains, and has a Mesozoic basement. The particular location of the basin implies that the northwestern depression has been subjected to both compressional and transpressional tectonic conditions (Peng and Zheng 1995). Specifically, the location suggests that the area was a compressional and fault-depressed basin from the Mesozoic to the Palaeogene. Since the Miocene, the peripheral fault belts have been rapidly uplifted and the entire Qaidam Basin has subsided as a result of closing of the Tethys tectonic domain and distant collision effects. The proto-Qaidam Basin was a compressional, depressed basin (Zheng and Peng 1995).

\section{Methods}

In this study, core samples were obtained from 11 boreholes (figure 1). These samples were mainly 


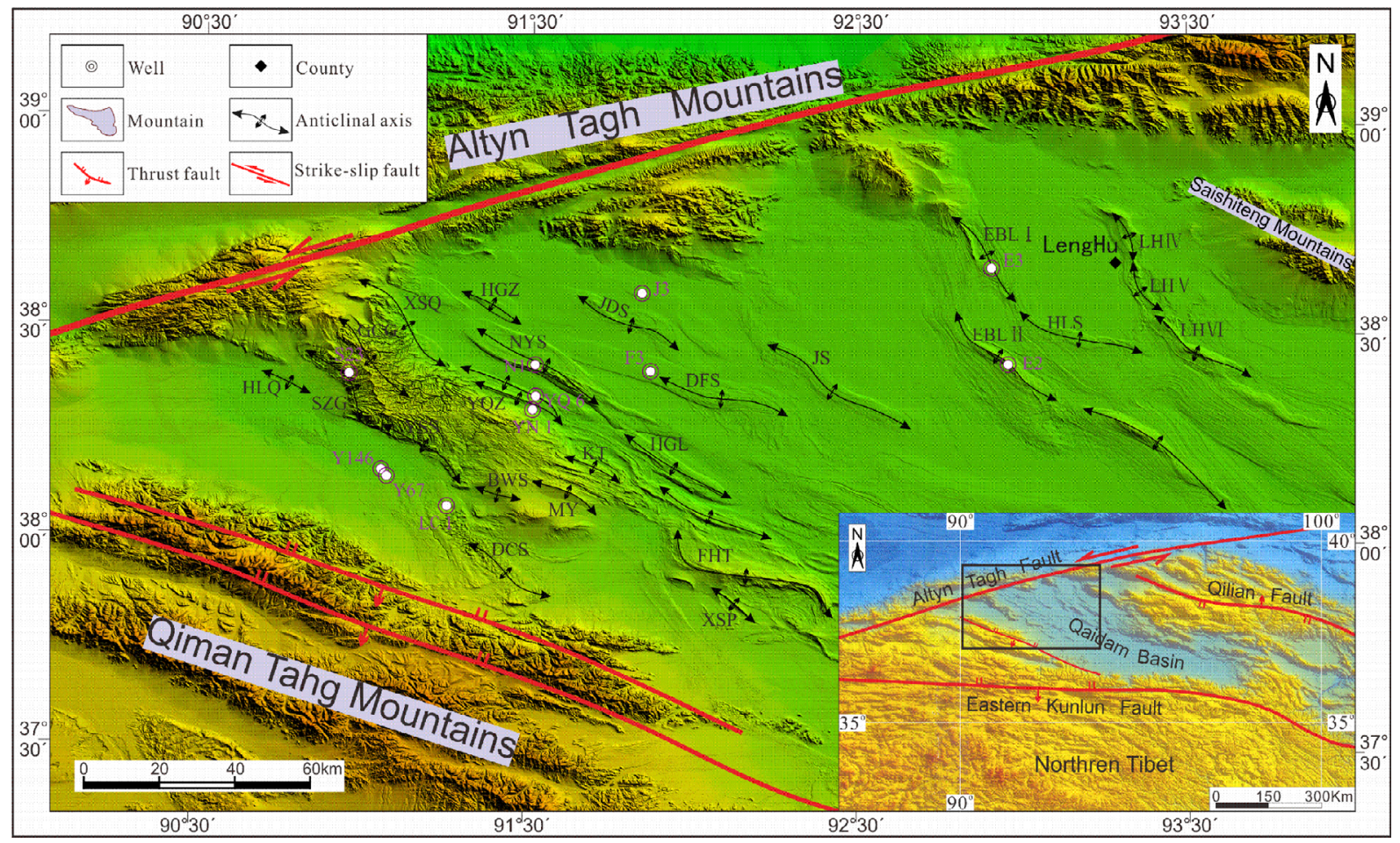

$\mathrm{HLQ}=$ Hongliuquan, $\mathrm{SZG}=$ Shizigou, $\mathrm{GCG}=$ Ganchaigou, $\mathrm{XSQ}=$ Xianshuiquan, $\mathrm{HGZ}=$

Honggouzi, YSS = Youshashan, YQZ = Youquanzi, NYS = Nanyishan, JDS = Jiandingshan, BWS

$=$ Beiwusi, $\mathrm{DCS}=$ Dongchaishan, $\mathrm{MY}=$ Mangya, $\mathrm{KT}=$ Kaite, $\mathrm{HGL}=$ Huanggualiang, $\mathrm{DFS}=$

Dafengshan, FHT $=$ Fenghuangtai, XSP $=$ Xiaoshaping, JS = Jianshan, EBL I = Eboliang, EBL II

$=$ Eboliang II, HLS $=$ Hulushan, LH IV = Lenghu IV, LH V = Lenghu V, LH VI = Lenghu VI.

Figure 1. Structural map of the northwestern depression of the Qaidam Basin with sampling locations marked.

sandstones, sandy mudstones, and muddy sandstones from the Palaeogene Xiaganchaigou Formation $\left(\mathrm{E}_{3}\right)$ and the Neogene Shangganchaigou Formation $\left(\mathrm{N}_{1}\right)$. The stratigraphically determined formation ages range from 37.5 to $22 \mathrm{Ma}$ (Wang et al. 2012; Jian et al. 2013), with burial depths of 1368.8-4416.55 m; more detailed information, such as strata position, lithology, and depth, is presented in table 1.

Apatite and zircon grains were separated from the host rocks by standard crushing, heavy-liquid separation, and magnetic separation procedures. Grains were mounted in epoxy on a Teflon plate then ground and polished to expose the internal crystal surfaces. To reveal the spontaneous tracks, apatites were etched at a constant temperature of $25^{\circ} \mathrm{C}$ in $6.6 \% \mathrm{HNO}_{3}$ for $30 \mathrm{~s}$ and zircons were etched at $220^{\circ} \mathrm{C}$ in a eutectic mixture of $8 \mathrm{~g} \mathrm{NaOH}$ and $11.5 \mathrm{~g} \mathrm{KOH}$ for $33 \mathrm{hr}$. Subsequently, muscovite with a low $\mathrm{U}$ content $(<5 \mathrm{ppb})$ was used as an 'external detector' to obtain the induced track densities. CN-5 uranium glass was used as a neutron dosimeter for apatite and $\mathrm{CN}-2$ was used for zircon. The sheet was irradiated in a reactor at a neutron fluence of $1.0 \times 10^{16} \mathrm{~cm}^{-2}$. After irradiation, the muscovite was placed in the external detector at $25^{\circ} \mathrm{C}$ in $40 \% \mathrm{HF}$ acid etching for $35 \mathrm{~min}$ to reveal induced fission-tracks. Apatite fissiontracks were counted using an Autoscan Professional Automated System (including a Zeiss Axio Imager M2m microscope, ES16 stage, and Fission Track Studio software) under a total magnification of $1000 \times$. Zircon fission-tracks were counted using a Zeiss microscope under a magnification of $1600 \times$ with oil immersion. Fission-track ages were calculated following the zeta calibration method (Hurford and Green 1983; Green 1985; Hurford 1990) with an apatite zeta value of $357.8 \pm 6.9(1 \sigma)$ and a zircon zeta value of $132.7 \pm 6.4(1 \sigma)$.

\section{Results and discussion}

All of the 11 samples were obtained from drilling cores. The buried depth is between 1368.8 and $4415.3 \mathrm{~m}$. From previous palaeotemperature 


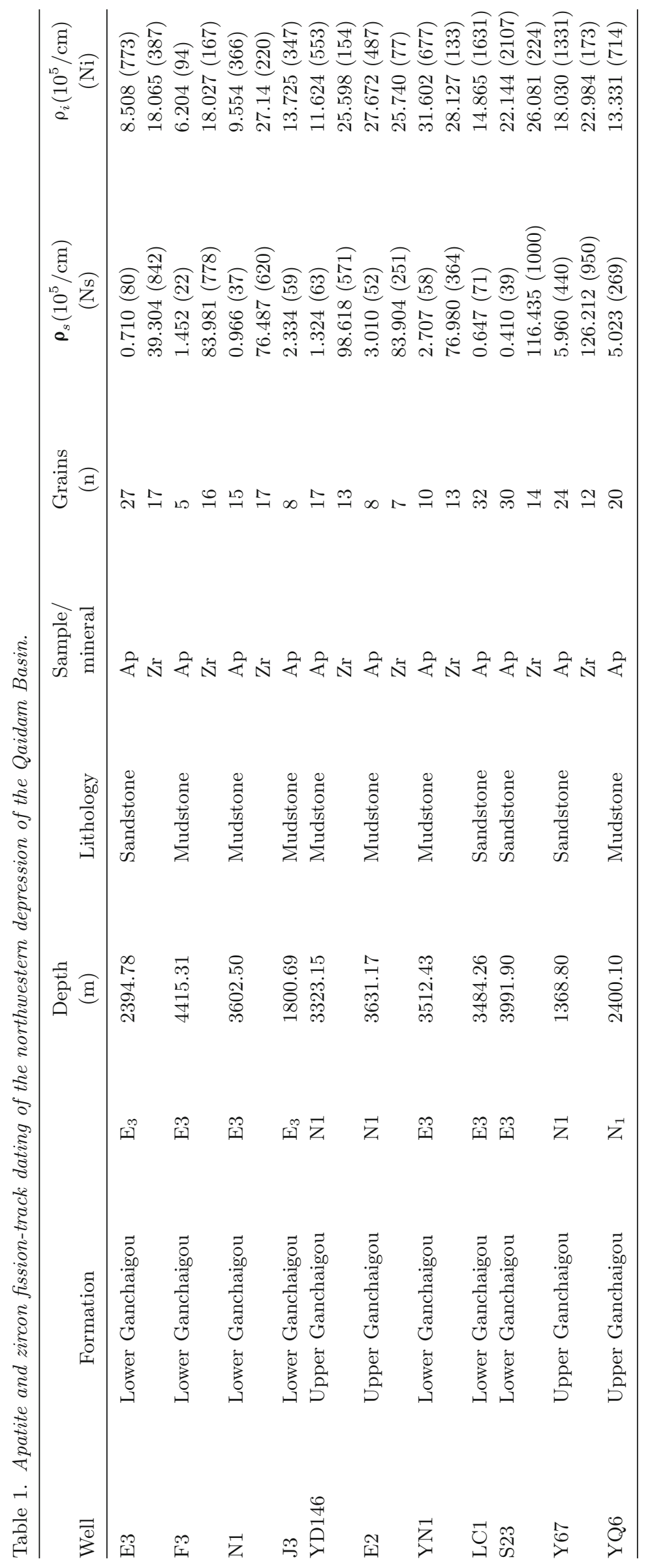




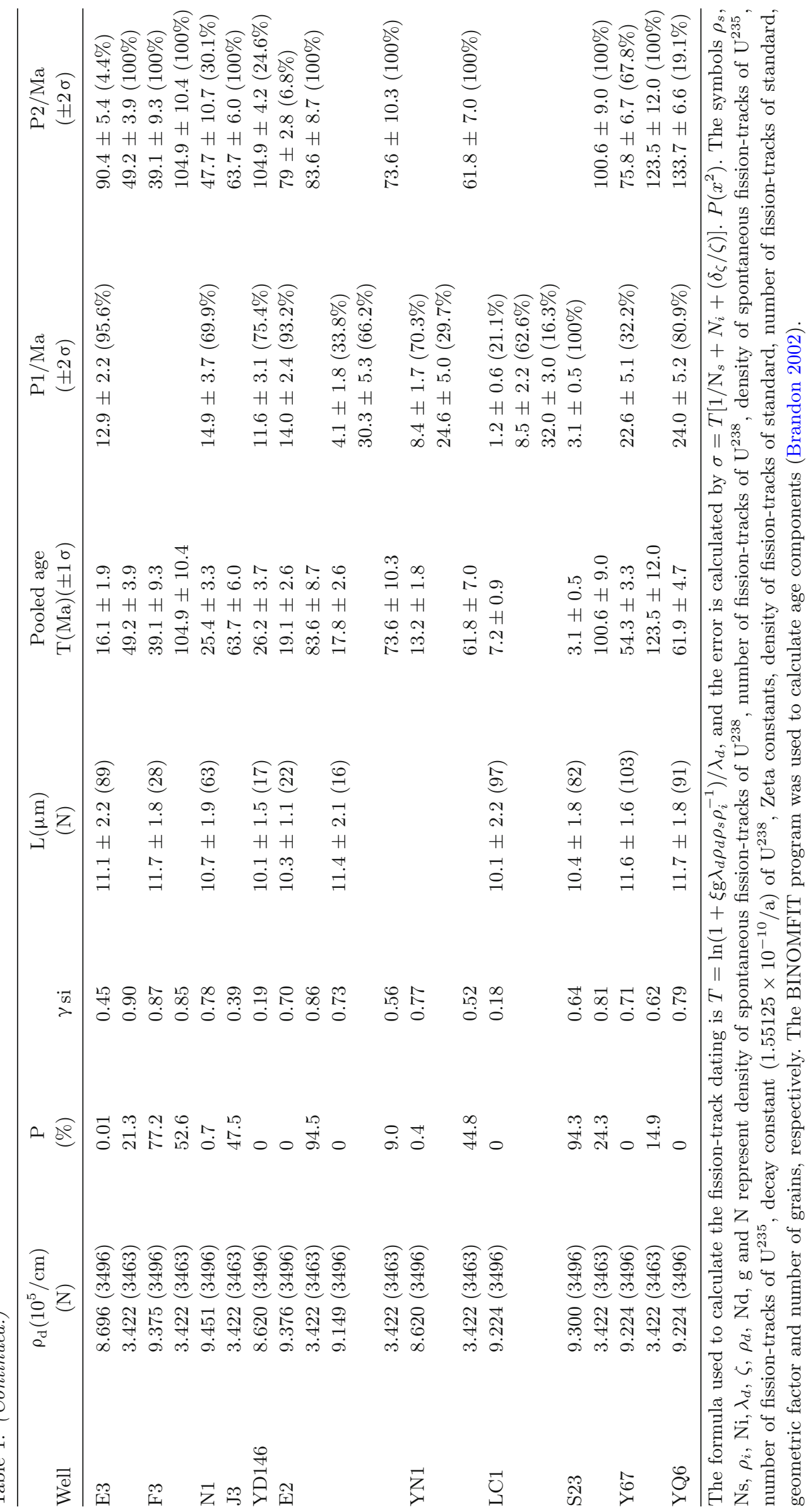


studies (Qiu et al. 2000; Zhong et al. 2004), these samples fall in the partial annealing zone of apatite (Green et al. 1986; Tagami et al. 1996), leading to partial or full annealing of apatite fission-tracks; however, the effects on the fission-tracks of zircon are smaller. The age distribution of sample grains from a single provenance obeyed the Poisson distribution of radioactive decay. Therefore, single-grain ages from apatite and zircon in sedimentary rocks represent the provenance cooling age, if the sedimentary rocks never experienced complete annealing. Galbraith and Green (1990) proposed a method to determine whether an individual grain age fits a Poisson distribution and ensure all grains belong to the same component. In their study, the parameter $\chi^{2}$ can be used to distinguish grain components, such that when $P\left(\chi^{2}\right)>$ $5 \%$, the mineral grains have variable provenance and multi-component analysis must be performed to determine the one-component age. Currently, routine methods used to discriminate age components are Gaussian peak fitting and binomial peak fitting (Galbraith and Laslett 1993; Brandon 1996).

The apatite fission-track ages of all samples show a wide range, from $3.1 \pm 0.5$ to $61.9 \pm 4.7 \mathrm{Ma}$. As the $P\left(\chi^{2}\right)$ values of 10 samples are less than $5 \%$, this implies that the fission-tracks were reformed by high burial temperatures and tectonic thermal events. Multi-component analysis was carried out to analyse the ages of samples that failed the $\chi^{2}$ text, and the results were expressed as a frequency distribution histogram of the same ages. Overall, the ages of all samples were consistent, and were distributed in two peak ranges: $1.2 \pm 0.6$ to $32.0 \pm 3.0 \mathrm{Ma}(\mathrm{P} 1)$ and $39.1 \pm 9.3$ to $133.7 \pm 6.6 \mathrm{Ma}(\mathrm{P} 2$; table 1 , figure 2$)$. The apatite fission-track lengths have a wide range and show two peaks, indicating that the samples were heated for a long time and experienced at least two tectonic events (Kang and Wang 1991; Zhu et al. 2001). The apatite fission-track peak age of 39.1-133.7 Ma perhaps represents the time of collision between the Kohistan Ladakh block in the Northwestern Indian plate and Eurasian plate, the other peak age of $1.2-32.0$ Ma may represent the time of collision between the Indian plate and the Eurasian plate along the Yarlung Tsangpo suture line.

The fission-track ages of eight zircon samples range between $49.2 \pm 3.9$ and $123.5 \pm 12.0 \mathrm{Ma}$. For all samples, $P\left(\chi^{2}\right)>5 \%$, indicating a uniform age structure (table 1, figure 3 ). This result implies that burial temperature did not influence these samples and they effectively preserve provenance age information. The fact that the zircon fission-track ages are older than the stratigraphic ages suggests that the Xiaganchaigou Formation and its overlying strata have not experienced high burial temperatures, and that zircon fission-tracks with no annealing can be used to study provenance.

Despite the complicated Mesozoic tectonic evolution, subduction of ocean crust and collision orogenesis of continental crust in northwestern China had ceased by the end of the Triassic, as shown by tectonic analysis and the peripheral fault belts of the Qaidam Basin formed at different times (Zheng et al. 2009). Collision of the East Kunlun fault belt finished in the Permian, while the main orogenic uplift persisted into the Ladinian Stage (Deway 1988; Zheng and Peng 1995), and the Qilian fault belt mainly closed and uplifted during the Caledonian stage (Wang and Ma 1984; Huang 1996; Lai et al. 1996; Zhao 1996; Yang et al. 1998). From the Early Triassic, northwestern China experienced intracontinental evolution where significant tectonic events resulted from the evolution of the southern Tethyan tectonic domain (Zheng et al. 2009). Major events included the collision of the Qiangtang block and the Eurasian Plate in the Late Triassic, the collision of the Lhasa block and the Eurasian Plate in the Late Jurassic, and the ongoing collision of the Indian and Eurasian plates since the Palaeogene. All of these events caused large-scale uplift of the Tibetan Plateau and East Kunlun fault belts (Howeii 1991; Zhou and Lin 1995) and intense sinistral strike-slip of the Altyn Tagh fault belt.

The tectonic setting and regional tectonic position of northwestern China has been affected by a number of geodynamic factors. From the Early Jurassic, northwestern China has contained several major fault belts in post-orogenic phases, including extension and strike-slip (Jia 1997; Guo and Zhang 1998; Jin et al. 1999; Chen and Wang 2000; Zuo et al. 2004). On the basis of the tectonic characteristics and evolution of the Qaidam Basin in the Jurassic and Cretaceous, previous studies found that the tectonic setting of the Qaidam Basin altered from an extensional to a compressional environment (Zhai et al. 1997; $\mathrm{Hu}$ et al. 1999; Zeng et al. 2002). In the Middle-Late Jurassic the Altyn Tagh region continued to subside and accumulate sediments derived from the central Qaidam Basin (Ma et al. 2006, 2009). In the Late 


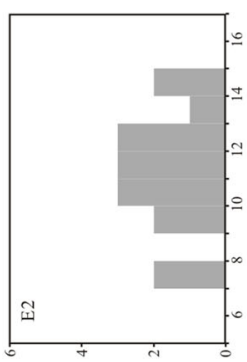

(N) Ḳฺฺuenò

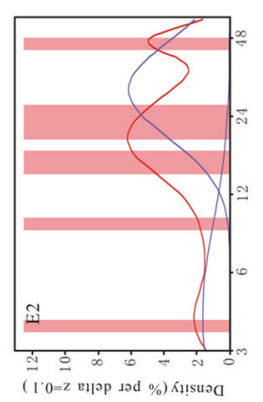

(
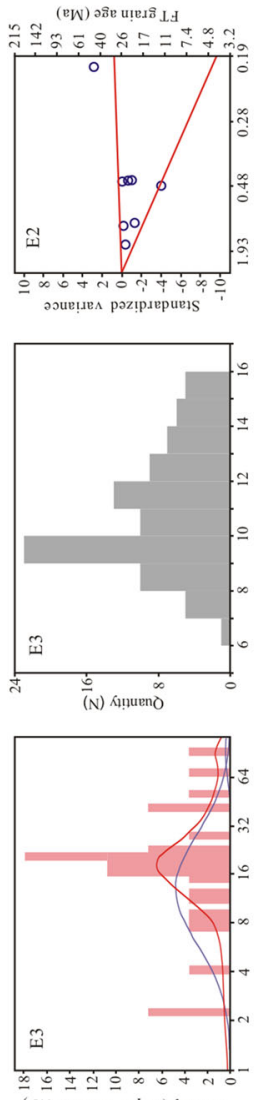

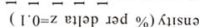

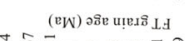

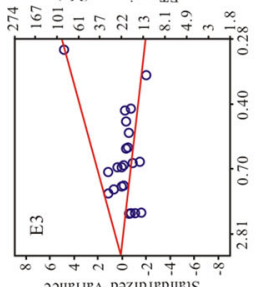

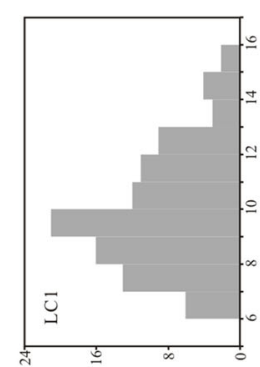

(N) K!̣uएu
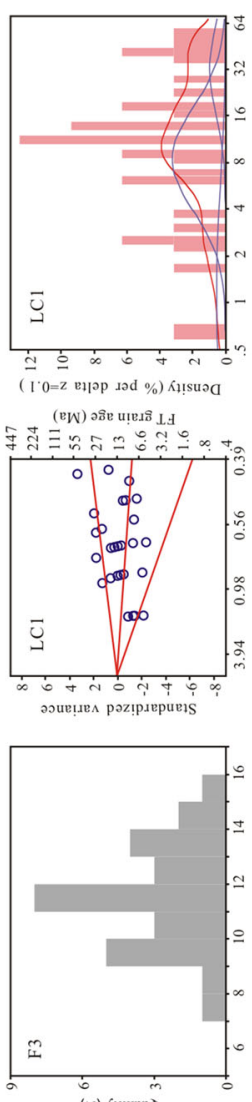

(N) Ḳฺueno

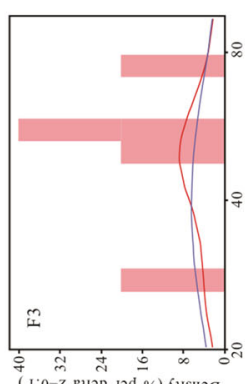

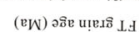

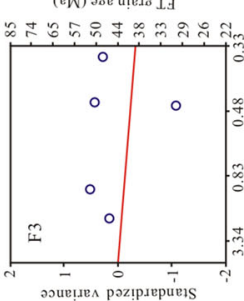

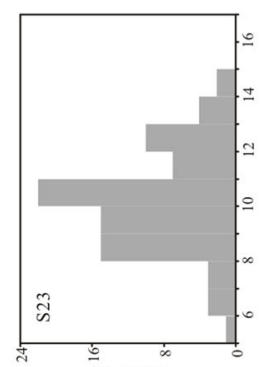

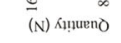

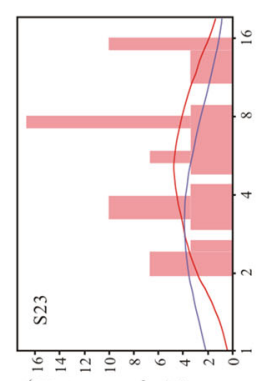

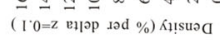

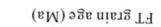

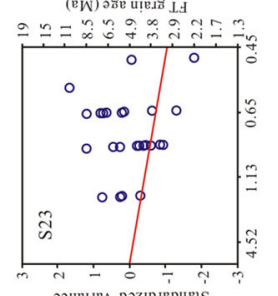

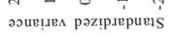

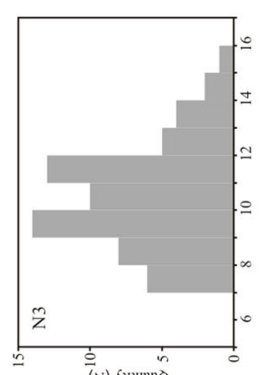

(N) Kụueno

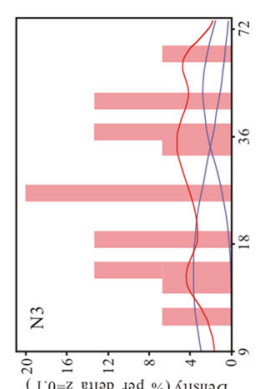

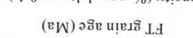

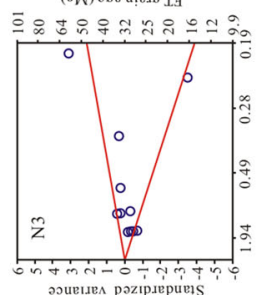

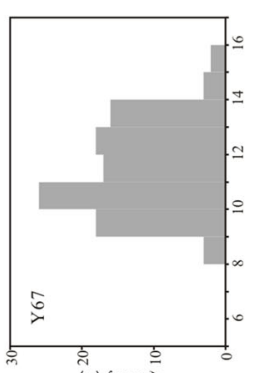

(N) ㅅำuenò

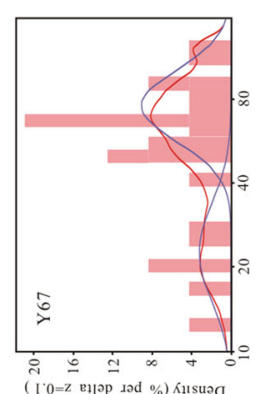

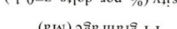
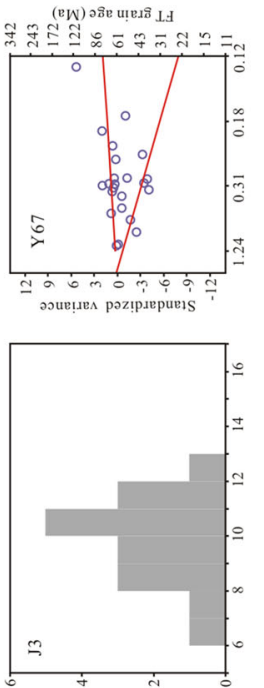

(N) Kịnueno

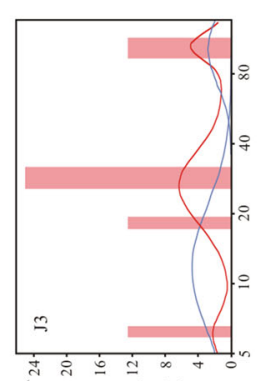

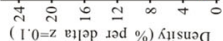

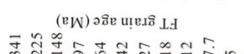

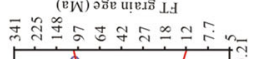

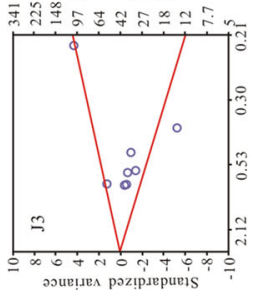

䒕 灵

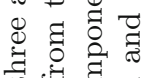

㟧

을

bo

당

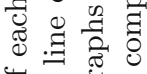

पे 00

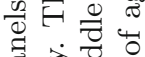

范苛

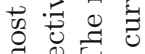

द्वे

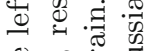

की

․ㅠ

药

ص⿺

घ.$\overline{1}$

预

O.

है

过苛

记

覀

要䨔.

घี चี

지 क्षे

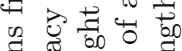

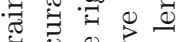

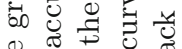

.

西告

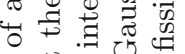

乎

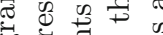

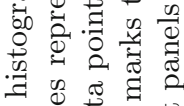

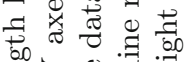

牙入

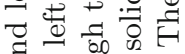

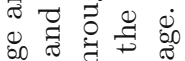

政

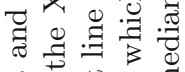

吃萧

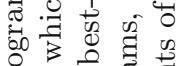

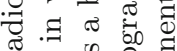

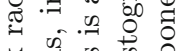

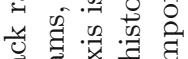
6 㻤

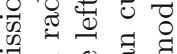

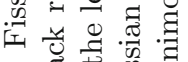

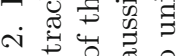
N

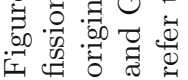



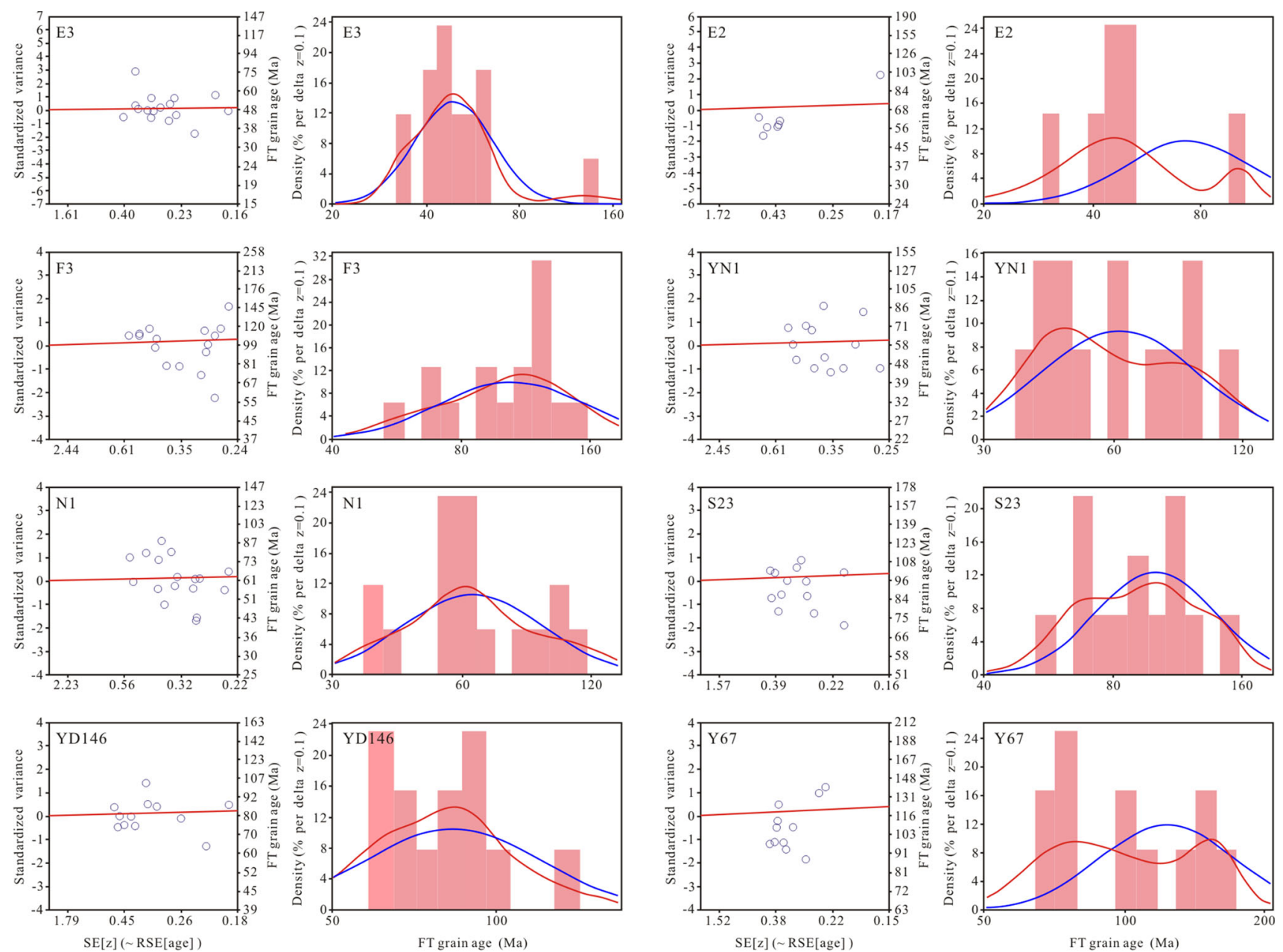

Figure 3. Fission-track radiograms and age histograms of zircons from the northwestern Qaidam Basin. The leftmost panels of each group of two are fission-track radiograms, in which the X and left $\mathrm{Y}$ axes represent the age accuracy and standard deviations of single grains, respectively. The line extending from the origin of the left Y-axis is a best-fit line through the data points to intersect the right $\mathrm{Y}$-axis, which indicates the age of that grain. The right panels are the age component and Gaussian curve histograms.

Cretaceous (102-85 Ma), the Kohistan Ladakh block in the northwestern Indian Plate collided with the Eurasian Plate (Jin 1999); subsequently, at 92-89 Ma, the deep part of the Altyn Tagh region commenced ductile strike-slip movement (figure 4a; Liu et al. 2001), forming the Altyn Tagh fault. During the middle-late Palaeogene the Altyn Tagh region began to be uplifted and eroded, becoming the primary sediment-supply area for the northwestern Qaidam Basin (Wang et al. 2012; Yi et al. 2013). The zircon fission-track ages (49.2 \pm 3.9 to $123.5 \pm 12.0 \mathrm{Ma}$ ) and apatite $\mathrm{P} 2$ age dates $(39.1 \pm 9.3$ to $133.7 \pm 6.6 \mathrm{Ma})$ recorded by fissiontrack annealing times are coincident with uplift of the Altyn Tagh mountains, also illustrating that the main Palaeogene sediment source for the northwestern Qaidam Basin was the Altyn Tagh mountains.
During the Cenozoic ( $\sim 45 \mathrm{Ma})$, the Indian and Eurasian plates collided along the Yarlung Tsangpo suture line (Chung et al. 1998), as a result of which, the Tibetan Plateau experienced intense horizontal compression. The Qaidam Basin extruded east along the Altyn Tagh strike-slip fault and experienced distant effects from the collision of the Indian and Eurasian plates (Howeii 1991). The Altyn Tagh strike-slip fault gradually expanded from a deeper stratigraphic layer into a shallower position because of dragging from deep ductile strike-slip movement (figure $4 \mathrm{~b}$ ). The East Kunlun and Qilian fault belts uplifted and thrust into the basin. Compressive stress from the western and northern Qaidam Basin caused continuous uplift of the basement and shifted the depositional centre eastward and then southeastward (Sun et al. 2004). With further intensification of the collision between the 

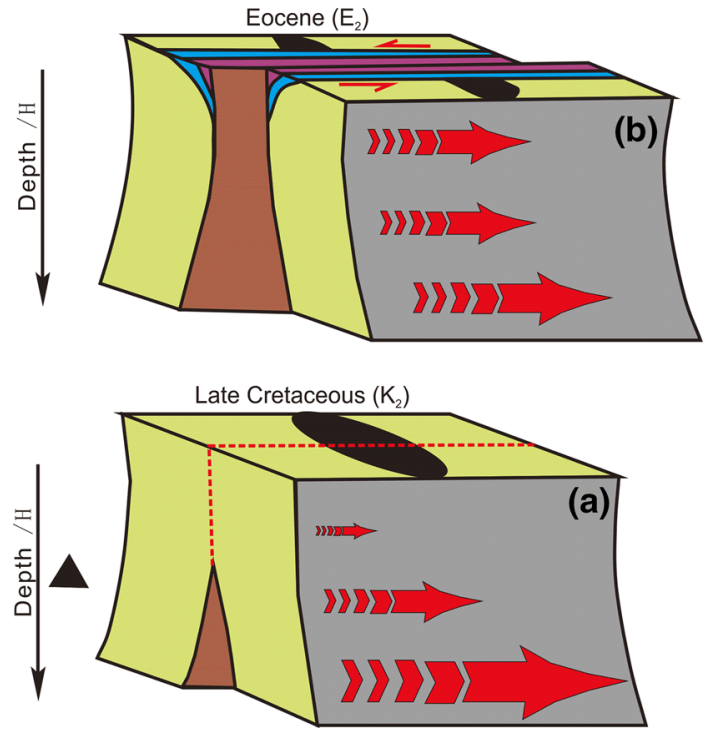

Figure 4. Evolution of the Altyn Tagh strike-slip fault (modified after Liu et al. 2001). (a) At the end of the Mesozoic era, the Tibetan plateau started to uplift alone with the collision between the Indian and Eurasian plates. The eastern Kunlun active fault zone, which locates in the south rim of the Qaidam basin, gradually thrust into basin. Under the remote effects of collision, the uplift and ductile strike-slip motion in Altyn region began. The second peak age of AFT (P2) and the age of zircon reflect the tectonic thermal events happened in this period; (b) at the end of Eocene, the collision between Indian and Eurasian plates became stronger, and collision zone gradually advanced to the Yarlung Zangbo River. Altun Tagh fault developed from deep ductile strike slip to surface fracture, and formed the large strike-slip fault finally. The total displacements of strike slide reached about $400 \mathrm{~km}$. The first peak age of AFT (P1) indicate the tectonic events during this period.

Indian and Eurasian plates, the response of the Qaidam Basin to collisional stress was increasingly obvious in two respects: (1) the eastern extrusion of the Qaidam block along the Altyn Tagh strike-slip fault resulted in transpressional stress in the peripheral and internal regions of the basin; and (2) continuous thrusting of peripheral faultfold belts caused intense horizontal compression that was significant for the formation of structural traps. Early anticlines developed further, and new anticlines formed in shallow strata as a result of the collision between the Indian and Eurasian plates. The $\mathrm{P} 1$ apatite component age $(1.2 \pm 0.6$ to $32.0 \pm 3.0 \mathrm{Ma}$ ) clearly records this annealing process of gradually increasing burial depth and temperature.

The northwestern region of the Qaidam Basin was evidently controlled by the Altyn Tagh strikeslip fault, where deep ductile strike-slip formed thrust faults and basement-involved structures beginning in the Late Cretaceous and continuing until the Oligocene. As a result of dynamic conversion and intensified activity of the Altyn Tagh strike-slip fault, transpressional effects were strengthened and have gradually affected the surface since the Oligocene-Miocene. A large number of transpressional structures developed linearly with a backward S-shape (Liu et al. 2001). Delamination and discordance between deep structures and shallow structures are clearly visible in seismic sections (Sun et al. 2012), where the peak position of these structures has evidently shifted. Most deep structures terminate in the rocks below the Shangganchaigou Formation and have been modified by later tectonic activity. Shallow structures mainly developed in the upper part of the Shangganchaigou Formation and were well preserved as petroleum traps with little modification by later tectonic activity.

\section{Conclusions}

Based on the analysis of zircon and apatite fissiontrack ages of core samples from 11 boreholes in the northwestern depression of the Qaidam Basin, we determined that the basin experienced two tectonic events since the late Mesozoic, at $39.1 \pm 9.3$ to $133.7 \pm 6.6 \mathrm{Ma}$ and $1.2 \pm 0.6$ to $32.0 \pm 3.0 \mathrm{Ma}$. The earlier tectonic event resulted from the initial collision of the Indian and Eurasian plates. During this event, peripheral fault belts began to develop, mountain ranges uplifted, and the proto-Qaidam Basin began to form in a compressional environment. The later tectonic event was caused by further collision of the Indian and Eurasian plates along the Yarlung Tsangpo suture zone. As a result of transpressional forces on deep structures, shallow structures such as anticlines started to develop. The later tectonic events caused further development of previous structures, facilitated development of many shallow structures, and played a crucial role in allowing shallow accumulation of petroleum.

\section{Acknowledgements}

This study was supported by the 'Western Light' Talents Training Program of CAS, Nature Science Foundation of Gansu Province (Grant No. 1308RJZA310) and the Key Laboratory Project of Gansu Province (Grant No. 1309RTSA041). 


\section{References}

Bao Z K, Yuan W M, Dong J Q and Gao S K 2005 Apatite fission track dating and thermal history of Qing-He Region in Altay Mountains; Nucl. Sci. Tech. 28 722-725.

Bovet P M, Ritts B D, Gehrels G, Abbink A O, Darby B and Hourigan J 2009 Evidences of Miocene crustal shortening in the north Qilian Shan from Cenozoic stratigraphy of the western Hexi Corridor, Gansu Province, China; Am. J. Sci. 4 290-329.

Brandon M T 1996 Probability density plot for fission-track grain-age samples; Radiat. Meas. 26 663-676.

Brandon M T 2002 Decomposition of mixed grain age distributions using BINOMFIT; Track 24 13-18.

Burbank D W and Beck R A 1989 Early Pliocene uplift of the Salt Range: Temporal constraints on thrust wedge development, northwest Himalaya, Pakistan; Spec. Papers Geol. Soc. Am. 232 113-128.

Chen F J and Wang X W 2000 Prototype analysis of early middle Jurassic basins in northwestern China; Geosci. Front. 7 459-468.

Chen Z L, Zhang Y Q, Chen X H, Wang X F, Ramon A S and Zack W B 2001 Late Cenozoic sedimentary process and its response to the slip history of the central Altyn Tagh fault, NW China; Sci. Sci. China Earth Sci. 44 $103-11$.

Chen A D, Wan J L and Guo T L 2004a Application examples of research on tectonic uplift by using fission-track dating; Acta Petrol. Sin. 25 29-32.

Chen Z L, Wang X F, Yin A, Chen B L and Chen X H 2004b Cenozoic left-slip motion along the central Altyn Tagh Fault as inferred from the sedimentary record; Int. Geol. Rev. 9 839-856.

Chung S L, Lo C H, Lee T Y, Zhang Y Q, Xie, Y W, Li X H, Wang K L and Wang P L 1998 Diachronous uplift of the Tibetan plateau starting 40 Myr ago; Nature 394 $769-773$

Dai S, Fang X M, Song C H, Gao J P, Gao D L and Li J J 2005 Early stage tectonic uplift of the northern Tibetan plateau; Chinese Sci. Bull. 50 673-683.

Dayem K E, Molnar P, Clark M K and Gregory A H 2009 Far-field lithospheric deformation in Tibet during continental collision; Tectonics 28 1-9.

Deway J F 1988 Extensional collapse of orogens; Tectonics 7 1123-1139.

Dupont-Nivet G, Horton B K, Butler R F, Wang J, Zhou $\mathrm{J}$ and Waanders G L 2004 Paleogene clockwise tectonic rotation of the Xining-Lanzhou region, northeastern Tibetan Plateau; J. Geophys. Res. 109 657-681.

Galbraith R F and Green P F 1990 Estimating the component ages in a finite mixture; Nucl. Tracks Radiat. Meas. 17 197-206.

Galbraith R F and Laslett G M 1993 Statistical models for mixed fission track ages; Nucl. Tracks Radiat. Meas. 21 459-470.

Gao J P, Fang X M, Song C H, Li S X and Xue J P 2011 Tectonic-thermo events of northern Tibetan plateau: Evidence from detrital apatite fission track data in western Qaidam basin; J. Jilin U. 41 1466-1475.

Green P F 1985 Comparison of zeta calibration baselines for fission-track dating of apatite, zircon and sphene; Chem. Geol. 58 1-22.
Green P F, Duddy I R, Gleadow A J W, Tingate P R and Laslett G M 1986 Thermal annealing of fission tracks in apatite: 1. A qualitative description; Chem. Geol. $\mathbf{5 9}$ $237-253$.

Guo Z J and Zhang Z C 1998 Structural style and tectonic evolution of the basins in the Altun Region; Geol. Rev. 44 357-364.

Howeii D G 1991 Terrane Tectonics - mountain building and continental growth; Translated by Wang C S, Qian Y Z and Li H Y in English, Sichuan Science and Technology Press, pp. 36-73.

Hu S Q, Cao Y J, Huang J X and Mou Z H 1999 Discussion on formation and evolution of Jurassic basin-prototype of Qaidam basin; Petrol. Geol. Exper. 21 189-195.

Huang J Q and Chen J W 1987 Evolution of the Tethyan Tectonic Domain; Science Press.

Huang R H 1996 Geotectonic evolution and its characteristics in Qilianshan Region; Geotect. Metal. 20 95-104.

Hurford A J and Green P F 1983 The zeta age calibration of fission-track dating; Chem. Geol. 41 285-317.

Jia C Z 1997 Structural characteristics and hydrocarbon in Tarim basin; Petroleum Industry Press, Beijing.

Jian X, Guan P, Zhang D W, Zhang W, Feng F, Liu R J and Lin S D 2013 Provenance of Tertiary sandstone in the northern Qaidam basin, northeastern Tibetan Plateau: Integration of framework petrography, heavy mineral analysis and mineral chemistry; Sedim. Geol. 290 109-125.

Jiang W, Mo X X, Zhao C H, Guo T Y and Zhang S Q 1998 Mineral fission-track dates and research on uplifting velocity of Qinghai-Xizang Plateau; J. Geomech. 4 13-18.

Jin J Q, Zhao W Z, Xue L Q and Meng Q R 1999 Prototypes and evolution of Jurassic basins in NW China; Geol. Rev. 45 92-104.

Jin Z M 1999 Discovery of coesite-bearing eclogite from west Himalayan tectonic link and its enlightenment; Geol. Sci. Technol. Inf. 18 1-5.

Jolivet M, Brunel M, Seward D, Xy Z, Yang J, Roger F, Tapponnier P, Malavieille J, Arnaude N and Wu C 2001 Mesozoic and Cenozoic tectonics of the northern edge of the Tibetan Plateau: Fission-track constraints; Tectonophys. S1-2 111-134.

Kang T S and Wang S C 1991 Fission track - a method in geothermal history research; Science Press, Beijing.

Lai S C, Deng J F and Zhao H L 1996 Volcanism and tectonic setting furing Ordovician Period on north margin of Qaidam; J. Xi'an Polytech Univ. 18 8-14.

Li H L, Qiu N S and Jin Z J 2005a Thermal history of central area of the Tarim basin by apatite fission track analysis; Chin. J. Geol. 40 129-132.

Li X M, Wang Y J, Tan K X and Peng T P 2005b MesoCenozoic uplifting and exhumation on Yunkaidashan: Evidence from fission track thermochronology; Chin. Sci. Bull. 50 577-583.

Liu Y J, Ge X H, Ye H W, Liu J L, Franz N, Genser J, Pan H X and Ren S M 2001 Strike-Slip model for Altyn Tagh fault developed since late Mesozoic; Acta Sedimentol. Sin. 22 23-28.

Liu Y J, Genser J, Ge X H, Neubauer F, Friedl G, Chang L H, Ren S M and Handler R $2003{ }^{40} \mathrm{Ar} /{ }^{39} \mathrm{Ar}$ age evidence for Altyn Fault tectonic activities in western China; Chin. Sci. Bull. 18 2024-2030. 
Ma F, Zhong J H and Duan H L 2006 Study of middleupper Jurassic turbidites on the Altun slope in the western Qaidam basin; Geol. Rev. 5 618-625.

Ma F, Zhong J H, Gu J Y and Xu H X 2009 Geometric characters and Paleocurrent implications of the Trough cross stratification-An example of the Altyn mountain in the western Qaidam basin; Acta Geol. Sin. 1 115-122.

Mock C, Arnaud N O and Cantagrel J M 1999 An early unroofing in northern Tibet? Constraints from ${ }^{40} \mathrm{Ar}-{ }^{39} \mathrm{Ar}$ thermochronology on granitoids from the eastern Kunlun range (Qinhai, NW China); Earth Planet Sci. Lett. 171(1) 107-122.

Patel R C, Kumar Y, Lal N and Kumar A 2007 Thermotectonic history of the Chiplakot Crystalline Belt in the Lesser Himalaya, Kumaon, India: Constraints from apatite fission-track thermochronology; J. Asian Earth Sci. 29(2-3) 430-439.

Patel R C and Carter A 2009 Exhumation history of the Higher Himalayan Crystalline along DhauligangaGoriganga river valleys, NW India: New constraints from fission track analysis; Tectonics 28(3) 161-169.

Patel R C, Adlakha V, Singh P, Kumar Y and Lal N 2011a Geology, structural and exhumation history of the Higher Himalayan Crystallines in Kumaon Himalaya; India; $J$. Geol. Soc. India 77(1) 47-72.

Patel R C, Adlakha V, Lal N, Singh P and Kumar Y 2011b Spatiotemporal variation in exhumation of the crystallines in the NW-Himalaya, India: Constraints from fission track dating analysis; Tectonophys. 504(1) 1-13.

Patel R C, Sinha H N, Kumar B A and Singh P 2014 Basin provenance and post-depositional thermal history along the continental $\mathrm{P} / \mathrm{T}$ boundary of the Raniganj basin, eastern India: Constraints from apatite fission track dating; J. Geol. Soc. India 83(4) 403-413.

Patel R C, Singh P and Lal N 2015 Thrusting and backthrusting as post-emplacement kinematics of the Almora Klippe: Insights from low-temperature thermochronology; Tectonophys. 653 41-51.

Patel R C and Singh P 2016 Post-emplacement kinematics and exhumation history of the Almora Klippe of the Kumaun-Garhwal Himalaya, NW India: Revealed by fission track thermochronology; Int. J. Earth Sci. (Geol Rundsch) 105 1-14.

Pei J L, Sun Z M, Wang X S, Zhao Y, Ge X H, Guo X C, Li H B and Si J L 2009 Evidence for Tibetan Plateau uplift in Qaidam basin before Eocene-Oligocene boundary and its climatic implications; Earth Sci. 2 430-437.

Peng Z L and Zheng J J 1995 Classification of the chief sedimentary basins in China; Acta Sedimentol. Sin. 13 150-159.

Qiu N S, Gu X J, Ding L H, Chen G and Yang Q Z 2000 Tectono-thermal evolution of western Qaidam basin, northwest China; Chin. J. Geol. 35 456-464.

Shi X B, Wang L S, Guo S P, Wang J and Zhou G J 1998 Inverse of apatite fission track data for thermal history information and its limitation; Chin. J. Geol. 33 177-194.

Singer A M C 1992 Plate Tectonic Theory and Orogeny; Translated by Ding X and Zhou Z Y, Fudan University Publishing House.

Singh P, Patel R C and Lal N 2012 Plio-Plistocene insequence thrust propagation along the Main Central Thrust zone (Kumaon-Garhwal Himalaya, India): New thermochronological data; Tectonophys. 574-575(11) 193-203.

Sun G Q, Zheng J J, Hu H F, Zhang D W and Xu Z Y 2004 Discussion of the down-warped setting basin: Taking Qaidam basin as an example; Nat. Gas Geosci. 15 395400.

Sun G Q, Zheng J J, Su L, Liu X W, Yang X and Liu Y H 2010 Mesozoic-Cenozoic tectonic evolution in northwestern Qaidam basin; Nat. Gas Geosci. 21 212-217.

Sun G Q, Si D, Wang M, Shen Y S, Zhou F, Hao X M and Niu F 2012 The tectonic kinematic process and the types of oil and gas reservoirs in northern margin of Qaidam basin; Nat. Gas Geosci. 23 826-832.

Tagami T, Carter A and Hurford A J 1996 Natural longterm annealing of the zircon fission-track system in Vienna basin deep borehole samples: Constraints upon the partial annealing zone and closure temperature; Chem. Geol. 130 $147-157$.

Wan J L, Wang Y, Li Q, Wang F and Wang E Q 2001 FT evidence of northern Altyn uplift in Late-Cenozoic; Bull. Mineral Petrol. Geochem. 20 222-224.

Wan J L, Zheng D W, Zheng W J and Wang W T 2011 Modeling thermal history during low temperature by $k$-feldspar MDD and fission track: Example from Meso-Cenozoic tectonic evolution in Saishitengshan in the northern margin of Qaidam basin; Seismol. Geol. 33 369-382.

Wang A, Wang G C, Zhang K X and Garver I J 2010 An early Cenozoic tectonic event in eastern Kunlun Orogen, evidence from detrital fission track geochronology; Earth Sci. 35 737-746.

Wang G C and Yang W R 1998 Some progresses of research methods on the uplift and exhumation of Cenozoic; Geosci. Front. 5 151-156.

Wang G C 2002 A new approach to determine the exhumation history of the sediment provenance: Detrital zircon and apatite fission-track thermochronology; Geol. Sci. Technol. Inf. 21 35-40.

Wang J 1997 Some existing problems in uplift rate calculated by apatite fission-track analysis; Geol. Sci. Technol. Inf. 16 97-102.

Wang S C 1998 Apatite fission track and its application in thermal history analysis; Physics 27 227-231.

Wang Y and Ji Z J 1999 Progress of the methods on the recovery of the thickness of eroded strata in basin; $A d v$. Earth Sci. 14 482-486.

Wang Y D, Zheng J J, Zhang W L, Li S Y, Liu X W, Yang $\mathrm{X}$ and Liu Y H 2012s Cenozoic uplift of the Tibetan Plateau: Evidence from the tectonic-sedimentary evolution of the western Qaidam Basin; Geosci. Front. 2 175-187.

Wang Y S and Ma Y Q 1984 Characteristics and evolution of the tectonic system in Qinghai province; Qinghai-Tibet Plateau Geological Collected Works, Geological Publishing House, Beijing.

Wu Z H 1999 Use of fission track dating in studying the uplift history of orogenic belt; Geol. Sci. Technol. Inf. 18 27-32.

Yang J S, Xu Z Q, Li H B, Wu C L, Cui J W, Zhang J $\mathrm{X}$ and Chen W 1998 Discovery of eclogite at northern margin of Qaidam Basin, NW China; Chin. Sci. Bull. 43 $1755-1760$ 
Yang X Y, Zhang J J, Qi G W, Wang D C, Guo L, Li Y P and Liu J 2009 Structure and deformation around the Gyirong basin, North Himalaya, and onset of the south Tibetan detachment system; Sci. China Ser. D. 52 1046-1058.

Yi D H, Yang L, Ma F, Ma X M and Ni X L 2013 Provenance system analysis of the Lulehe formation in Paleogene of the east Altun slope; J. East Chin. Inst. Technol. (Nat. Sci. Edn) 3 302-306.

Yin A, Dang Y Q, Wang L C, Jiang W M, Zhou S P, Chen X H, Gehrels G E and McRivette M W 2008 Cenozoic tectonic evolution of Qaidam basin and its surrounding regions (Part 1): The southern Qilian Shan-Nan Shan thrust belt and northern Qaidam basin; Geol. Soc. Am. Bull. 7/8 813-846.

Yin A, Rumelhart P E, Butler R, Cowgill E, Harrison T MFoster D A, Ingersoll R V, Zhang Q, Zhou X Q, Wang X F, Hanson A and Raza A 2002 Tectonic history of the Altyn Tagh Fault system in northern Tibet inferred from Cenozoic sedimentation; Geol. Soc. Am. Bull. $101257-$ 1295.

Yuan W M, Zhang X T, Dones J Q, Tang Y H and Wang S C 2004 Apatite fission track evidence on the uplifting of eastern Kunlun mountains; Atom Energ. Sci. Technol. 38 166-168.

Yue Y J, Ritts B D and Graham S A 2001 Initiation and long-term slip history of the Altyn Tagh fault; Int. Geol. Rev. 12 1087-1093.

Yue Y J, Ritts B D, Graham S A, Wooden J L, Gehrels G E and Zhang Z C 2003 Slowing extrusion tectonics: Lowered estimate of post-Early Miocene long-term slip rate for the Altyn Tagh fault; Earth Planet Sci. Lett. $\mathbf{2 1 7}$ 111-122.

Zeng L B, Jin Z J, Zhang M L, Tang L J, You F B and Lei B Z 2002 The Jurassic basin type and its evolution characteristic in Qaidam basin; Acta Sedimentol. Sin. 20 288-292.

Zhai G M, Xu F Y and Li J Q 1997 A reconsideration of Qaidam basin for a great breakthrough in oil and natural gas exploration; Acta Petrol. Sin. 18 1-7.
Zhang Z C, Guo Z J, Li J F and Tang W H 2012 Mesozoic and Cenozoic uplift-denudation along the Altyn Tagh fault, northwestern China: Constraints from apatite fission track data; Quat. Sci. 32 499-509.

Zhao S G 1996 The features and tectonic evolution of the Qilian orogenic belt; Acta Geol. Gansu. 5 16-29.

Zhao Z D, Mo X X, Guo T Y, Zhou S, Dong G C, Wang L L, Zhang F Q and Wang J L 2003 Fission track ages of pluton in South Tibet and plateau uplift; Prog. Nat. Sci. $13877-880$.

Zheng D W, Zhang P Z, Wan J L, Yuan D Y, Zhang G L and Li C Y 2005 Apatite fission track evidence for the thermal history of the Liupanshan basin; Chinese J. Geophys. 48 $157-164$.

Zheng J J and Peng Z L 1995 Tectonic kinematic process of chief oil-gas bearing basins and the formation of oil-gas in China; Acta Sedimentol. Sin. 13 160-168.

Zheng J J, Su L, Liu X W, Yang X, Sun G Q, Zhang S C and Liu Y H 2009 The conversion of dynamical mechanisms and formation of intra-plate depression under the compress (-shear) dynamics; Geotect. Metal. 33 107-114.

Zhong J H, Guo Z Q, Yang S F, Liu W H, Chen H L, Huang L G, Liu Y T, Jiang B and Zhang Y S 2004 Vertical distribution of the tertiary vitrinite reflectivity (Ro) and its geological significance in the western Qaidam basin; Acta Geol. Sin. 78 407-415.

Zhou Z Y and Lin H L 1995 Stratum, palaeogeography and plate tectonics in northwestern China; Nanjing University Publishing House.

Zhu W B, Wan J L, Shu L S, Sun Y and Wang F 2004 Mesozoic-Cenozoic thermal history of Turpan-Hami basin: Apatite fission track constraints; Prog. Nat. Sci. 14 1194-1198.

Zhu Y M, Qin Y, Zhang Y S and Li T Z 2001 Fission track analysis and evolution of Paleozoic source rocks headed in Huanghua Depression; J. China Coal Soc. 2 113-116.

Zuo G C, Liu Y K and Li X B 2004 Jurassic basinrange tectonic pattern and depositional features of prototype basins in the inner Mongolia-Gansu-Qinghai-Ningxia region; Geol. Bull. China 23 261-271. 